\title{
Water Quality of Freshwater Ecosystems in a Temperate Climate
}

\author{
Piotr Klimaszyk $(D)$ and Ryszard Gołdyn *D \\ Department of Water Protection, Adam Mickiewicz University, Uniwersytetu Poznańskiego 6, \\ 61-614 Poznań, Poland; pklim@amu.edu.pl \\ * Correspondence: rgold@amu.edu.pl
}

Received: 7 September 2020; Accepted: 18 September 2020; Published: 22 September 2020

\begin{abstract}
Water is the substance that made life on Earth possible. It plays a key role in both the individual and population development of all species. Water is also a critical resource for humans as populations continue to grow and climate change affects global and local water cycles. Water is a factor limiting economic development in many regions of the world. Under these conditions, good water quality becomes an extremely important factor that determines its economic utility, including water supply, recreation, and agriculture. Proper water quality maintenance of freshwater ecosystems is also very important for preserving biodiversity. The quality of water depends on many factors, the most important of which are related to human impact on water ecosystems, especially the impact of various pollutants from municipal economy, industry and agriculture. Hydrotechnical changes, such as river damming, drainage processes and water transport between catchments also have a significant impact. Water quality is also dependent on the impact of natural conditions connected, e.g., with climate, catchment, water organisms and their interactions within the food-webs, etc. This Special Issue consists of fourteen original scientific papers concerning different problems associated with the water quality of freshwater ecosystems in a temperate climate. Most of the articles deal with the relations between water quality and the structure of ecosystem biocenoses. The conclusion of these articles confirms the fact that the deterioration of water quality has a direct impact on the quantitative and qualitative structure of biocenoses. This is accompanied by a decline in biodiversity and the disappearance of rare plant and animal species. They also draw attention to the particular importance of internal physical and chemical differentiation within the aquatic ecosystem, both in horizontal and vertical dimensions. The problem of ensuring proper ecological conditions and good quality of water in freshwater aquatic ecosystems is also raised, and methods for the restoration of water bodies are presented. The majority of the research presented in this Special Issue was carried out in Central Europe, and one of the papers concerns the area of West Africa-the edge of temperate climate zone.
\end{abstract}

Keywords: water quality; eutrophication; biodiversity; aquatic plants; plankton assemblages; water cycle; European Water Framework Directive; freshwater ecosystems restoration

\section{Introduction}

Earth water resources contain a huge amount of water (about 1.4 billion cubic kilometers). However, only $3 \%$ of this amount is freshwater. It is surprising, but only $1 \%$ of the total amount of freshwater is stored in surface freshwater ecosystems (lakes, rivers, ponds and reservoirs) [1]. Proper water quality enables the use of many ecosystem services by human beings. It also maintains the stable functioning of water ecosystems and ensures high biodiversity, both within the waterbody and in the entire landscape. Freshwaters are strictly connected with their surrounding terrestrial ecosystems and cumulate (lakes, ponds, reservoirs) or transport (streams and rivers) matter and energy from catchments. Natural catchment area traits, e.g., geology, morphology, climate, determine 
the strength and scale of the impacts. Undisturbed catchment areas usually deliver insignificant amounts of pollutants, so deterioration of water quality and rise in trophy are slow and imperceptible. Occasionally, natural phenomena may cause rapid deterioration of the water quality of ecosystems, but most often they are local or limited in time [2-4]. A rapid increase of human population leads to a shift in water and chemical elements within the landscape and ecosystems that finally triggers freshwater eutrophication and deterioration of water quality. Deforestation and transformation of natural catchments into agriculture and industrial areas lead to changes in the water cycle. A decrease of water retention in the catchment accelerates water outflow and increases the loads of nitrogen, phosphorus, carbon, calcium and other chemical elements reaching the freshwaters $[5,6]$. The increase of heavy rainfall events associated with global climate change is causing intensified erosion and washing of nutrients and other chemical substances from catchments that affect the water quality of waterbodies. Another serious threat to water quality is industrial origin atmospheric deposition of nitrogen and sulfur that acidify freshwaters. Loads of $\mathrm{N}$ and $\mathrm{S}$ reaching lakes and rivers not only decrease water $\mathrm{pH}$ but also increase the bioavailability of $\mathrm{C}$ and $\mathrm{N}[7,8]$.

External nitrogen and phosphorus loads frequently reach surface waters with treated municipal sewage, discharged directly or flowing with ground waters [4,9]. Very large loads also originate from agriculture; they can be particularly intensive in the case of large farms using high doses of mineral fertilizers. They are non-point sources, reaching the waterbody along the entire shoreline $[10,11]$. Excessive nutrient concentration causes a hypereutrophic state of waterbodies, which is manifested by an intensive growth of phytoplankton, loss of submerged vegetation and a decrease in the biodiversity of benthic macroinvertebrates [12]. Recent decades have given rise to emerging pollutants, i.e., pharmaceuticals, which affect water quality [13] and modify the functioning of water ecosystems [14].

Degraded aquatic ecosystems require protective measures that eliminate or limit the inflow of external pollutants. Often, however, these treatments are not sufficient and must be supplemented with restoration treatments. Their main goal is to improve water quality in the waterbody, but for this to be possible, it is necessary to change the functioning of the entire ecosystem. Restoration treatments are usually very expensive, so nature-based solutions that use natural processes taking place in the ecosystem to improve water quality are increasingly preferred $[9,15,16]$. It is very advantageous to use several restoration methods simultaneously, thus reducing the possibility of feedback effects that can eliminate the positive effects of individual methods [17].

The problem of the bad ecological status of water resources-groundwater, lakes, rivers and other fresh and coastal waters-is of particular interest to the European Commission. In 2000, the Commission implemented the Water Framework Directive (WFD) to ensure sustainable water management based not on political or administrative boundaries but on basins units. The WFD provides a legal framework that obliges EU countries to prevent the deterioration of the aquatic environment and to achieve a good status of all water bodies.

The WFD identifies the most important causes of water degradation, prescribes the reduction and control of pollution and recommends sustainable water use. It also establishes requirements for the assessment and monitoring of water quality. In the case of surface waters, the WFD pays more attention to the ecological state of the ecosystem's biocenoses than to water quality, defined by physical, chemical and hydromorphological indicators, which are of auxiliary nature. The main aim of the WFD is to achieve good ecological status for natural waters and the ecological potential of artificially changed water bodies. The first deadline set for EU countries to meet this target was 2015. However, due to unsatisfactory progress, the Commission decided to derogate, and eventually set 2027 as the date. However, there are serious concerns that many countries will not be able to achieve this goal by that date either [18]. Therefore, protective and restoration measures should be widely implemented to improve the current ecological status of freshwater.

We hope that this Special Issue discussing the problems related to the water quality of freshwater ecosystems in a temperate climate will contribute to a better understanding of the causes of water 
quality deterioration, the mechanisms responsible for the functioning of ecosystems and the possibilities of improving their condition.

\section{Summary of the Issue}

The articles published in this Special Issue cover a wide range of aspects connected with the water quality of freshwater ecosystems in a temperate climate.

Zieliński et al. [4] used the chemical tool: strontium isotopes $\left({ }^{87} \mathrm{Sr} /{ }^{86} \mathrm{Sr}\right)$ to identify water supply and track the source of pollution of meromictic Lubińskie Lake (N Poland). They found that the main factor affecting the lake's water quality is the nutrient inflow from the catchment. Despite a wide ecotone zone that acts as a sink for non-point sources of pollutants, nitrogen and phosphorus migrate from croplands, infiltrate the first aquifer and enter the lake through springs. The deep aquifer and good quality water supply is of secondary importance in the Lubińskie Lake water budget. In meromictic lakes, the lack of total horizontal mixing prevents the water quality of the upper layer (mixolimnion) from deteriorating because the deep layer (monimolimnion) acts as a trap for both autochthonous and allochthonous pollutants [19]. The authors found that several subsequent heavy storms that occurred in 2008 had broken the multiannual stratification of the lake. The consequence of these phenomena was an upwelling of the nutrient rich water of the monimolimnion and a deterioration of the surface water of the lake.

Two further articles $[10,20]$ deal with the problem of water quality changes in soft-water lakes with isoetids. Soft water lakes with isoetids are considered as valuable natural habitats and are included in the Natura 2000 protected area network as habitat 3110-“Oligotrophic waters containing very few minerals of sandy plains (Littorelletalia uniflorae)". They are prone to degradation due to the low buffer capacity of their waters [20].

Zawiska et al. [10] performed a paleolimnological assessment of the functioning of the soft water Lake Sekšu in Latvia, which is under long term stress due to the artificial supply of eutrophic pumped water. Before the commencement of water pumping (1950s) Lake Sekšu was a low productive water body with some symptoms of eutrophication. It was inhabited by characteristic plant species: Lobelia dortmanna, Isoëtes lacustris and Juncus bulbosus. Diatom-based total phosphorus (TP) reconstruction indicates between 25 and $50 \mu \mathrm{g} \mathrm{L}^{-1}$. After 10 years of water pumping, lake level had risen and total $\mathrm{P}$ concentration had increased to over $100 \mu \mathrm{g} \mathrm{L}^{-1}$. Closing the inflow of eutrophic waters led to a slight decrease of the total P concentration. The rapid increase trophic state of the lake increased the abundance of diatoms causing a decrease in water transparency, which induced hypolimnetic oxygen deficits. This caused the vanishing of characteristic plant species and the emergence of eutrophic species.

Klimaszyk et al. [20] describe long-term changes in the water chemistry and transformation of biocenosis of one of the largest Polish soft water lake with isoetids, Lake Jelen. The lake is located within the borders of the city of Bytów and is under recreational pressure. Since the beginning of 1990s, a gradual increase in the trophic state of the lake has been observed as indicated by increased nutrient availability, deterioration of deep-water oxygen conditions and a decrease in water transparency. The alterations in water chemistry induced biological transformations, in particular, an increase in phytoplankton abundance (4-fold increase of biomass in the epilimnion) as well as a gradual reduction in the range of the phytolittoral (from 10 to $6 \mathrm{~m}$ ), a decrease in the frequency of isoetids, and expansion of plant species characteristic of a eutrophic state. At the same time, a very rare charophyte species Nitella translucens has been observed in the lake since the beginning of the 20th century [21].

Babko et al. [22] present the results of studies on the structure of the ciliate population in a floodplain eutrophic lake. The authors show that the main factor responsible for the spatial distribution of ciliates in a floodplain eutrophic waterbody is the pattern of habitat oxygenation. According to results, the authors distinguished four characteristic habitats: (i) habitat with permanent high oxygen concentration, (ii) habitat with permanent low oxygen concentration, (iii) permanent anoxic habitat, 
and (iv) habitat with high diurnal fluctuations of oxygen concentration. They concluded that a high diversity of habitats ensures high biodiversity in water bodies.

The authors of the next article [23] come to similar conclusions to those of Babko et al. [22]. Antonowicz and Kozak [23] study the concentration of chemical parameters and biocenoses occurring in the surface microlayer, i.e., the ecotone, between the hydrosphere and the atmosphere. They prove that the surface microlayer is characterized by a specific chemical and biological composition. Compared to the deeper zone, the surface microlayer accumulates more trace metals, nutrients and magnesium. The authors also found a higher abundance of heterotrophic bacteria and phytoplankton in the surface microlayer. Taxonomic analysis of the phytoneuston showed that the surface microlayer is a separate habitat.

Kirichenko-Babko et al. [24] deal with the problem of the impact of river pollution and transformation of riverbanks of floodplain lakes on the assemblages of riparian ground beetles. The authors state that rivers with their floodplains are some of the most diverse and biologically productive ecosystems, but at the same time, they are among the most prone to human impact. The obtained results show that riverbanks and floodplain lakes are habitats with different characteristics. They identified 95 species of ground beetles, of which 81 species were found on riverbanks, and 51 species were found on the shores of floodplain lakes. The authors found that the expansion of vegetation on the open banks of the river (resulting from the increase of river eutrophication) significantly affects the species composition and spatial distribution of the riparian ground beetles. The number and density of riparian species decreases with increasing development of the vegetation cover.

Czerniawski et al. [12] describe the impact of human activity on the structure of invertebrates in a small urban stream. The composition of invertebrates was strongly influenced by the human impacts occurring in both the streambed and catchment. The authors found that spatial differentiation of the richness and abundance of zooplankton in the studied stream increased with an increase in the distance from the river source. The highest richness of zooplankton was stated in river pools where the water current was slower. Only a small number of macroinvertebrate taxa were found in all sections of the studied river. The authors hypothesized that this is the result of the regulation of stream banks, deforestation of the catchment and water pollution.

Kuczyńska-Kippen [11] presents the results of studies on the response of zooplankton community indices to abiotic, biotic, and habitat traits in two types of ponds differing in the level of human stress. Ponds of low human alterations characterize richer communities and a higher share of littoral zooplankton, whose occurrence was associated with higher water transparency and complex macrophyte habitats. Plankton communities predominated in the highly human-influenced ponds. Their distribution was mainly related to the open water area and fish presence. Anthropogenic disturbance was also reflected in the frequency of rare species, which were more related to low impacted ponds. Despite the fact that the majority of rare species are littoral-associated, they had no prevalence towards a certain ecological type of plant, which suggests that any kind of plant cover, even macrophytes typical for eutrophic waters, will create a valuable habitat for pond conservation. The author postulates that a complex and dense cover of submerged macrophytes ought to be maintained in order to improve the ecological value of small water bodies.

Napiórkowski et al. [25] studied the relationship between zooplankton communities of floodplain lakes with the degree of their connection with rivers and flood-pulse dynamics. They found higher diversity and abundance of zooplankton in floodplain lakes connected with river compared to permanently isolated ones. The authors also noticed that the river flood-pulse has an impact on the zooplankton diversity in the studied lakes. The high level of the river and therefore the studied lakes increased zooplankton diversity and the predomination of rotifer density. When the level of a river is low, total diversity decreased, but crustacean density rose. Research shows that the stable functioning and high diversity of floodplains requires a mosaic of river habitats. The regulation of rivers and cutting off floodplain lakes from their connection with rivers disturbs specific hydrological conditions and leads to an impoverishment of water biocenoses. 
Nouaceur and Murarescu [26] studied rain variability in West Africa. To analyze rainfall trends and variability, the authors used long term data from 27 Sahelian climatic stations in Burkina Faso, Mauritania and Senegal and a chronological graphic method of information processing (MGCTI) of the "Bertin Matrix" and continuous wavelet transformation (CWT). The results of the analysis of rainfall trend evolution showed that, following a long Sahelian drought, rains returned to this part of West Africa. The change from the dry to the wet period began in the second half of the 1990s; however, the level of rainfall did not reach the maximum values noted in the 1950s. The authors argue that this return of rainfall is related to the surface temperature of the Atlantic Ocean.

The European Water Framework Directive requires that all European waterbodies should achieve at least good ecological quality. Rücker et al. [18] analyzed the effects of long-term measures to achieve a good ecological status of North German lowland lakes. The authors studied the influence of morphometry, land use, catchment size, and hydrology on water quality. They noticed that despite great efforts, $70 \%$ of German lakes have not achieved proper ecological status. They identified excessive nutrient emissions from agriculture as the main cause of this failure. Based on long-term data, they analyzed the response of two morphometrically differentiated lakes to the reduction of nutrient loads. In the case of shallow polymictic lakes, even significant long-term reduction of external loads of nutrients did not result in changes in biocenoses or satisfactory improvement of ecological status. Therefore, catchment size in relation to lake area or volume becomes a major predictor for the probability of lakes reaching at least a good ecological quality.

Undoubtedly, achieving an improvement in ecological status requires, in the case of many aquatic ecosystems, not only a decrease in the inflow of nutrients from the catchment area but also a number of technical treatments within the waterbody itself [17]. Dondajewska et al. [15] present data on the sustainable restoration of a dimictic lake. The strongly eutrophicated lake was treated for almost 10 years with hypolimnetic aeration, phosphorus inactivation using small doses of chemicals and top-down biomanipulation. During that period, the authors noticed a gradual improvement of oxygen conditions in the lake hypolimnion. Induced nitrogen transformation in the deep-water zone resulted in a 30\% decrease in the concentration of ammonium nitrogen and a decrease in phosphorus content. The reduction of nutrient content lead to a lower phytoplankton biomass, expressed in a 55\% decrease of chlorophyll-a concentrations and a two-fold increase in water transparency.

One of the expected effects of lake restoration is the reduction of phytoplankton abundance and the elimination of potentially toxic taxa of cyanobacteria. Kozak et al. [16] present data on changes in the functional groups of phytoplankton in a long-term restored lake. The small postglacial eutrophic lake was initially treated with iron sulfate to inactivate phosphorus. This treatment did not bring about the expected outcome. Some rebuilding of phytoplankton functional groups was observed; however, continuous domination of cyanobacteria species such as Aphanizomenon gracile, Planktolyngbya limnetica, and Limnothrix redekei indicated a highly eutrophic and turbid state of the lake. The second stage of restoration consisting in the delivery to the over-bottom zone of the lake water of nearby streams rich in oxygen and nitrate led to a significant change in the phytoplankton structure. Species of groups characteristic for eu-mesotrophic waters started to dominate.

The control of phytoplankton blooms is one of the greatest environmental engineering challenges. The addition of hydrogen peroxide to the aquatic ecosystem and the generation of reactive oxygen species has been shown to selectively target cyanobacteria that create harmful water blooms. Thoo et al. [27] studied the effect of increasing the concentration of reactive oxygen species on zooplankton as a result of adding sodium percarbonate. They found that the genus Daphnia shows moderate sensitivity to sodium percarbonate, although the size of specimens affects the probability of survival. The lower likelihood of survival of larger individuals may be related to a higher relative filtration rate. The results of the studies show that a safe concentration of sodium percarbonate for Daphnia individuals would be below $10.0 \mathrm{mg} \mathrm{L}^{-1}$ of sodium percarbonate $\left(2.8 \mathrm{mg} \mathrm{L}^{-1}\right.$ of hydrogen peroxide). The presence of zooplankton, especially large daphnids, is a key factor in controlling the 
biomass and phytoplankton structure. Therefore, the use of too high a dose of oxidants may cause side effects and lead to the failure of restoration treatment.

Author Contributions: Conceptualization and writing, P.K.; text completion and editing, R.G. All authors have read and agreed to the published version of the manuscript.

Funding: This research received no external funding.

Conflicts of Interest: The authors declare no conflict of interest.

\section{References}

1. Holden, J. Water fundamentals. In Water Resources: An Integrated Approach; Holden, J., Ed.; Routledge Taylor and Francis Group: London, UK; New York, NY, USA, 2014; p. 371.

2. Spencer, C.N.; Gabel, K.O.; Hauer, F.R. Wildfire effects on stream food webs and nutrient dynamics in Glacier National Park, USA. For. Ecol. Manag. 2003, 178, 141-153. [CrossRef]

3. Klimaszyk, P. May a cormorant colony be a source of coliform and chemical pollution in a lake? Oceanol. Hydrobiol. Stud. 2012, 4, 67-73. [CrossRef]

4. Zieliński, M.; Szczucińska, A.; Drożdżyński, M.; Frankowski, M.; Pukacz, A. Water quality assessment of a meromictic lake based on physicochemical parameters and strontium isotopes (87Sr/86Sr) analysis: A Case Study of Lubińskie Lake (Western Poland). Water 2019, 11, 2231. [CrossRef]

5. Barałkiewicz, D.; Chudzińska, D.; Szpakowska, B.; Świerk, D.; Gołdyn, R.; Dondajewska, R. Storm water contamination and its effect on the quality of urban surface waters. Environ. Monit. Assess. 2014, 186, 6789-6803. [CrossRef]

6. Klimaszyk, P.; Rzymski, P. Catchment vegetation can trigger lake dystrophy through changes in runoff water quality. Ann. Limnol. Int. J. Limnol. 2013, 49, 191-197. [CrossRef]

7. Klimaszyk, P.; Rzymski, P. Surface runoff as a factor determining trophic state of midforest lake. Pol. J. Environ. Stud. 2011, 20, 1203-1210.

8. Shigaki, F.; Sharpley, A.; Prochnow, L.I. Rainfall intensity and phosphorus source effects on phosphorus transport in surface runoff from soil trays. Sci. Total Environ. 2017, 373, 334-343. [CrossRef]

9. Dondajewska, R.; Kozak, A.; Budzyńska, A.; Kowalczewska-Madura, K.; Gołdyn, R. Nature-based solutions for protection and restoration of degraded Bielsko Lake. Ecohydrol. Hydrobiol. 2018, 18, 401-411. [CrossRef]

10. Zawiska, I.; Dimante-Deimantovica, I.; Luoto, T.P.; Rzodkiewicz, M.; Saarni, S.; Stivrins, N.; Tylmann, W.; Lanka, A.; Robeznieks, M.; Jilbert, T. Long-term consequences of water pumping on the ecosystem functioning of Lake Sekšu, Latvia. Water 2020, 12, 1459. [CrossRef]

11. Kuczyńska-Kippen, N. Response of zooplankton indices to anthropogenic pressure in the catchment of field ponds. Water 2020, 12, 758. [CrossRef]

12. Czerniawski, R.; Sługocki, Ł.; Krepski, T.; Wilczak, A.; Pietrzak, K. Spatial changes in invertebrate structures as a factor of strong human activity in the bed and catchment area of a small urban stream. Water 2020, 12, 913. [CrossRef]

13. Rzymski, P.; Drewek, A.; Klimaszyk, P. Pharmaceutical pollution of aquatic environment: An emerging and enormous challenge. Limnol. Rev. 2017, 17, 92-107. [CrossRef]

14. Klimaszyk, P.; Rzymski, P. Water and aquatic fauna on drugs: What are the impacts of pharmaceutical pollution? In Water Management and the Environment: Case Studies. WINEC 2017. Water Science and Technology Library; Zelenakova, M., Ed.; Springer: Cham, Switzerland, 2018; Volume 86, pp. 255-278. [CrossRef]

15. Dondajewska, R.; Kowalczewska-Madura, K.; Gołdyn, R.; Kozak, A.; Messyasz, B.; Cerbin, S. Long-term water quality changes as a result of a sustainable restoration-A case study of dimictic Lake Durowskie. Water 2019, 11, 616. [CrossRef]

16. Kozak, A.; Budzyńska, A.; Dondajewska-Pielka, R.; Kowalczewska-Madura, K.; Gołdyn, R. Functional groups of phytoplankton and their relationship with environmental factors in the restored Uzarzewskie Lake. Water 2020, 12, 313. [CrossRef]

17. Gołdyn, R.; Podsiadłowski, S.; Dondajewska, R.; Kozak, A. The sustainable restoration of lakes-Towards challenges of the water framework directive. Ecohydrol. Hydrobiol. 2014, 14, 68-74. [CrossRef]

18. Rücker, J.; Nixdorf, B.; Quiel, K.; Grüneberg, B. North German lowland lakes miss ecological water quality standards-A lake type specific analysis. Water 2019, 11, 2547. [CrossRef] 
19. Klimaszyk, P.; Heymann, D. Vertical distribution of benthic macroinvertebrates in a meromictic lake (Lake Czarne, Drawienski National Park). Oceanol. Hydrobiol. Stud. 2010, 39, 99-106. [CrossRef]

20. Klimaszyk, P.; Borowiak, D.; Piotrowicz, R.; Rosińska, J.; Szelag-Wasielewska, E.; Kraska, M. The effect of human impact on the water quality and biocoenoses of the soft water lake with isoetids: Lake Jeleń, NW Poland. Water 2020, 12, 945. [CrossRef]

21. Rosińska, J.; Piotrowicz, R.; Celiński, K.; Dabert, M.; Rzymski, P.; Klimaszyk, P. The reappearance of an extremely rare and critically endangered Nitella translucens (Charophyceae) in Poland. J. Phycol. 2019, 55, 1412-1415. [CrossRef]

22. Babko, R.; Kuzmina, T.; Danko, Y.; Szulżyk-Cieplak, J.; Łagód, G. Oxygen gradients and structure of the ciliate assemblages in floodplain Lake. Water 2020, 12, 2084. [CrossRef]

23. Antonowicz, J.P.; Kozak, A. Phytoneuston and chemical composition of surface microlayer of urban water bodies. Water 2020, 12, 1904. [CrossRef]

24. Kirichenko-Babko, M.; Danko, Y.; Franus, M.; Stępniewski, W.; Babko, R. Riparian ground beetles (Coleoptera) on the banks of running and standing waters. Water 2020, 12, 1785. [CrossRef]

25. Napiórkowski, P.; Bąkowska, M.; Mrozińska, N.; Szymańska, M.; Kolarova, N.; Obolewski, K. The effect of hydrological connectivity on the zooplankton structure in floodplain lakes of a regulated large river (the Lower Vistula, Poland). Water 2019, 11, 1924. [CrossRef]

26. Nouaceur, Z.; Murarescu, O. Rainfall variability and trend analysis of rainfall in West Africa (Senegal, Mauritania, Burkina Faso). Water 2020, 12, 1754. [CrossRef]

27. Thoo, R.; Siuda, W.; Jasser, I. The effects of sodium percarbonate generated free oxygen on Daphnia-Implications for the management of harmful algal blooms. Water 2020, 12, 1304. [CrossRef]

(C) 2020 by the authors. Licensee MDPI, Basel, Switzerland. This article is an open access article distributed under the terms and conditions of the Creative Commons Attribution (CC BY) license (http://creativecommons.org/licenses/by/4.0/). 